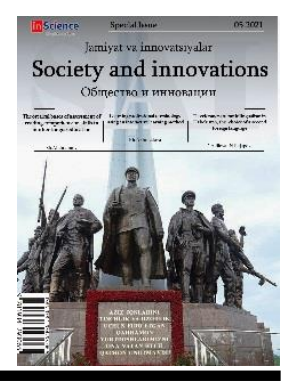

\title{
Improving vocational and pedagogical training of future technological education teachers
}

\author{
Shahnoza KULIEVA' ${ }^{1}$, Kamola KHOLMATOVA ${ }^{2}$ \\ Bukhara State University
}

\begin{tabular}{l} 
ARTICLE INFO \\
\hline Article history: \\
Received April 2021 \\
Received in revised form \\
20 April 2021 \\
Accepted 15 May 2021 \\
Available online \\
25 June 2021
\end{tabular}

\footnotetext{
Keywords:

personality,

technology,

pedagogical education,

continuity of education,

socialization of education,

equivalence of education,

pedagogical reflection,

professional development.
}

\begin{abstract}
In the article, the future of technological education is considered as a process of realizing the potential of the personal and professional development of a future teacher, and creativity is considered as an objective need in the design of one's professional activity. The ideas of individual design of the process of professional training of teachers are considered as an objective leading criterion of professional pedagogical education. 2181-1415/C) 2021 in Science LLC.

This is an open access article under the Attribution 4.0 International (CC BY 4.0) license (https://creativecommons.org/licenses/by/4.0/deed.ru)
\end{abstract}

\section{Бўлажак технологик таълим ўқитувчиларининг касбий- педагогик тайёргарлигини такомиллаштириш}

\author{
Калит сўзлар: \\ шахс, \\ технология, \\ педагогик таълим, \\ таълимнинг узлуксизлиги, \\ таълимнинг \\ ижтимоийлашуви, \\ таълимнинг \\ эквивалентлиги, \\ педагогик аксланиш, \\ касбий шакллантириш.
}

\begin{abstract}
АННОТАЦИЯ
Мақолада бўлажак технологик таълим ўқитувчиларини тайёрлашда кабий-педагогик тайёргарлигини такомиллаштириш хамда самарадорлигини оширишда бўлажак ўқитувчининг шахсий ва касбий ривожланиши ўз имкониятларини рўёбга чиқариш жараёни, ижодкорлик эса касбий фаолиятини лойихалашга бўлган объектив эхтиёж сифатида қаралади. Ўқитувчининг касбий тайёргарлик жараёнини индивидуал лойихалаш ғоялари касбийпедагогик таълимнинг объектив етакчи мезони хақида фикр юритилган.
\end{abstract}

\footnotetext{
${ }^{1} \mathrm{PhD}$, associate professor, Bukhara State University. Bukhara, Uzbekistan.

2 1-course master, Bukhara State University. Bukhara, Uzbekistan.
} 


\section{Совершенствование профессиональной и педагогической подготовки будущих преподавателей технологического образования}

\author{
Ключевые слова: \\ личность, \\ технология, \\ педагогическое \\ образование, \\ преемственность \\ образования, \\ социализация \\ образования, \\ эквивалентность \\ образования, \\ педагогическая \\ рефлексия, \\ профессиональное \\ становление.
}

\begin{abstract}
АННОТАЦИЯ
В статье будущее технологического образования рассматривается как процесс реализации потенциала личностного и профессионального развития будущего учителя, а творчество - как объективная потребность в проектировании своей профессиональной деятельности. Идеи индивидуального проектирования процесса профессиональной подготовки учителей рассматриваются как объективный ведущий критерий профессионального педагогического образования.
\end{abstract}

Инсоният тарихи мавжуд босқичининг мохияти ижтимоий маданиятнинг замонавий цивилизация, тараққиёт келтириб чиқарган муаммолар таъсирида яна бир бор тарихий синовдан ўтаётганлиги тавсифланади. Айни вақтда, жамият тараққиётида ижтимоий жараённи жадаллаштирувчи технологик ривожланишнинг хал қилувчи ахамият касб этишини эътиборга олиб, уни техноген цивилизация деб аташ мумкин. Бундай цивилизациянинг асоси муайян қадриятлар тизимига қурилади.

Педагогик фаолиятнинг инсонпарварлик тамойилига асосланувчи парадигмаси қуйидаги мезонларга таянади:

- таълимнинг ижтимоийлашуви - ўқитувчиларни тайёрлаш жараёнига нисбатан технократик ёндашувдан воз кечиш, улар томонидан нисбатан ўзлаштириладиган билимлар мажмуасининг педагогик хамда психологик хусусият касб этишини таъминлаш, ўқитувчиларда умуминсоний, умуммаданий қадриятлар мазмунида илгари сурилган ғояларга асосланган ижтимоий тафаккурни шакллантириш;

- миллий хамда жахон маданияти асослари ва уларнинг мохиятидан хабардор бўлиш;

- таълим ва тарбия жараёнини ташкил этишда миллий истиқлол ғояларига асосланиш;

- шахснинг ўз-ўзини ривожлантириш хамда мустақил таълим олишга бўлган лаёқатига таяниш ва уни такомиллаштириш;

- ўқитувчиларнинг касбий жихатдан шакллантириш жараёнида ўқитувчи хамда талабаларнинг ўзаро хамкорликда фаолият олиб боришларига эришиш;

- таълим (хусусан, касб таълими) жараёнида ўқув дастурларининг талабалар қобилияти хамда қизиқишларига кўра танлаб олиниши борасидаги имкониятнинг мавжудлиги;

- педагогик таълимнинг фундаментал хусусият касб этиши, яъни, талабалар томонидан ўзгарувчан шароитларда шахс ижодий ривожи асосини таъминловчи инвариант билимларнинг ўзлаштирилишига эришиш; 
- мехнат бозори хамда ижтимоий жараёнларда юзага келувчи хамда доимий равишда ўзгариб турувчи, эхтиёжларга тўлақонли жавоб бера оладиган таълим тизимини шакллантириш, шу асосда касбий мослашувчан мутахассисларни тарбиялаш;

- таълимнинг узлуксизлиги, таълимнинг хар бир жараён босқичининг натижаланишини таъминловчи касбий таълим (кадрлар малакасини ошириш хамда уларни қайта тайёрлаш) дастурларининг тизимининг яратиш ва ривожлантириш, муайян дастурни таълимнинг у ёки бу босқичида ўқитилиши ёки ўқишни бошқа типдаги ўқув муассасасида давом эттира олиш имкониятини бера олиши;

- таълимнинг эквивалентлиги, яъни унинг давлат таълим стандарти, миллий маданияти ва менталитет, шунингдек, халқаро меъёрларга мувофиқ даражаси.

Технологик таълим ўқитувчисининг касбий-педагогик тайёргарлигининг юқори даражада бўлишига эришиш қуйидаги холатлар мавжудлигини тақозо этади:

- ўқитувчининг касбий ва шахсий шаклланиш даражаси бу йўлда ташкил этилган жараённинг умумий мохиятини ёритувчи педагогик тизим самарадорлигига чамбарчас боғлиқлиги;

- ўқитувчининг касбий жихатдан шакллантиришни таъминловчи жараёнларининг ташкилий бошқаруви мақсадга мувофиқ тарзда такомиллашиб бориши;

- рефлексив бошқарув ўқитувчини касбий жихатдан шакллантиришдан кўзланган мақсаднинг натижаланишини кафолатлайди. Рефлексив бошқарув аниқ мақсадда ташкил этилаётган жараён хусусиятларини максимал даражада хисобга олиш, шунингдек, хар бир таъсирни унинг мазмунида намоён бўлувчи қонуниятлар билан мувофиқлаштиришни талаб этади.

Касб таълими ўқитувчисини касбий шакллантириш жараёнини ташкил этишда унинг умумий ташкилий асослари, мазмуни, шакл хамда методларини белгиловчи асосий қонуниятларни аниқлаш мухим ахамият касб этади.

Педагогик фаолият назарияси ва амалиётида мезонларнибелгилаш, уларни асослашга нисбатан умумий талаблар мавжуддир. Мазкур мезонлар шахс шаклланишининг асосий қонуниятларини ўзида акс эттириш билан бирга, таълим сохасида миқдор ўзгаришларнинг сифат ўзгаришларга ўсиб ўтишини таъминлайди.

Технологик таълим ўқитувчисини касбий шакллантиришни таъминловчи педагогик тизим мохиятини асословчи мезонлар бир қатор сифат кўрсаткичлари ёрдамида ифодаланадики, уларнинг аниқланиши қайд этилган мезоннинг ахамияти хусусида сўз юритиш имконини беради; иккинчидан, мезонлар ўлчанаётган сифат кўрсаткичининг вақт оралиғи, ижтимоий маданий мухит ва талаба шахсининг ривожланиб бориши жараёнидаги ўзгаришини ўзида акс эттира олиши лозим; учинчидан, мезонлар мумкин қадар педагогик фаолиятнинг барча жабхаларини қамраб олиши зарур.

Ўқитувчининг шахсий ва касбий ривожланиши ўз имкониятларини рўёбга чиқариш жараёни, ижодкорлик эса касбий фаолиятини лойихалашга бўлган объектив эхтиёж сифатида қаралади. Ўқитувчининг касбий тайёргарлик жараёнини индивидуал лойихалаш ғоялари касбий-педагогик таълимнинг объектив етакчи мезони бўлиб қолмоқда. 
Технологик таълим ўқитувчисини касбий шакллантиришнинг ташкилийметодик мезонлари сифатида қуйидагилар эътироф этилади:

Касбий таълим мазмунининг шахсга йўналтирилганлиги. Мазкур мезоннинг амалга оширилиши бўлажак ўқитувчиларни тайёрлаш жараёнини қуйидаги йўналишда ўзгартиришни кўзда тутади: ўқитувчининг бир бутун шахс сифатида ривожланиши, ўқитувчи онгини касбий фаолияти йўналишида қайта йўналтирилиши хамда ўқитувчининг касбий фаолиятига татбиқ этиши лозим бўлган идеал ва қадриятларни ўзлаштириши.

Касбий таълим мазмунининг касбий фаолиятга йўналтирилганлиги. Ушбу мезон биринчидан, ўқитувчининг шаклланиш жараёнини лойихалашнинг интеграл тавсифда эканлигини таъкидлайди; иккинчидан, уни лойихалашнинг аниқ шаклларини белгилайди; учинчидан, ўқитувчининг ижодий куч-қувватини ишга солиш йўлларини хамда воситаларини куррсатиб беради, бу билан уни педагогика фани ва амалиёт босиб ўтган йўлни қайта такрорламасликка олиб келади.

Касбий фаолиятнинг педагогик аксланиш (рефлексия) мезони. Бўлажак ўқитувчининг касбий шаклланиш жараёнида мазкур мезоннинг амалга оширилиши ўқитувчида ўзини шахс сифатида доимий такомиллаштириб боришга бўлган эхтиёжни тарбиялайди. Бунинг учун у касбий фикрлаш, рефлексив сифатларни ривожлантиради, аниқ касбий фаолиятни амалга ошириш учун мақсадга мувофиқ бўлган шакл ва методларни шакллантиради. Бу ўринда асосийси - касбий фаолият, яъни мақсад, фаолиятни амалга ошириш шароитлари тўғрисида тушунчалар, харакат дастури, фаолият натижаларини бахолаш мезонлари, фаолият натижаларини бахолашни рационал йўлга қўйиш холатларининг аниқланишидир. Мазкур мезон ўқитувчи харакатларининг тавсифини хамда усулларини белгилаб беради. Бунинг учун ўқитувчининг педагогик маданият тимсоли сифатидаги касбий фаолият модели унинг касбий хулқи учун намуна бўлиб қолади. Буларнинг хаммаси ўқитувчининг касбий такомиллашувга интилувчанлигини оширувчи шахснинг маънавий-ахлоқий қарашларини фаоллаштиради.

\section{ФОЙДАЛАНИЛГАН АДАБИЁТЛАР РЎЙХАТИ:}

1. Muhidova O.N. Methods and tools used in the teaching of technology to children // ISJ Theoretical \& Applied Science, 04 (84), (2020). - PP. 957-960.

2. Muhidova Olima Nurilloyevna. Forming technological competence using visual tools in technology lessons // Academicia: An International Multidisciplinary Research Journal. Vol. 11 Issue 1, January 2021. - PP. 852-855.

3. Muhidova O.N. Development of creative abilities in technology lessons // International journal of discourse on innovation, integration and education. Vol. 2 No. 2 (2021). - PP. 119-122.

4. Halimovna K.S., Nurilloevna M.O., Radzhabovna K.D., Shavkatovna R.G., Hamidovna The role of modern pedagogical technologies in the formation of students' communicative competence. // Religación. Revista De Ciencias Sociales Y Humanidades 4 No. 15 (2019): Special Issue May. - PP. 261-265.

5. Uzokov O.Kh., Muhidova O.N. Factor determining the efficiency of innovative activities of a teacher // International journal of discourse on innovation, integration and education. Vol. 2 No. 1 (2021). - PP. 81-84. 
6. О.Н. Мухидова. Компетентностный подход к развитию профессиональной деятельности учителя // Вестник науки и образования 97 (№ 19 (97). Часть 2). С. 88-91.

7. Мухидова О.Н. Электронное обучение в высшем образовании // Вестник магистратуры, 1-5 (100). - 2020. - С 43-44.

8. Кулиева Ш.Х., Расулова З.Д. Формирование профессионально-педагогической компетентности будущих специалистов на основе информационных технологий // Молодой учёный, 2016. № 8 (112). - С. 977-978.

9. Кулиева Ш.Х., Расулова З.Д. Инновационная деятельность педагога в образовании // Молодой учёный, 2016. № 8 (112). - С. 978-979.

10. Кулиева Ш.Х., Каримова М.Н. Использование современных дидактическое средств в обучении специальных предметов // Педагогические науки. Москва, 2015. №1. - С. 85-89.

11. Кулиева Ш.Х. Интенсификация процесса проектирования одежды // Молодой учёный. Казан, 2016. № 9 (113). - С. 193-196.

12. Кулиева Ш.Х. Методологические основы системного подхода при подготовке учителей // The Wayof Science. № 5 (39) ,2017. - С. 66-67.

13. Аноркулова Г.М., Кулиева Ш.Х., Расулова З.Д. Методологические основы системного подхода при подготовке учителей профессионального обучения // Молодой учёный. 93:13 (2015). - С. 588-590.

14. Аноркулова Г.М., Кулиева Ш.Х., Расулова З.Д. Модель подготовки учителей профессионального образования на основе системного подхода // Молодой учёный. 93:13 (2015). - С. 590-592.

15. Кулиева Ш.Х., Хамроева Х.Ю., Расулова З.Д. Учебный процесс как педагогическая система в процессе подготовки учителей профессионального обучения // Молодой учёный. 56:9 (2013). - С. 383-385.

16. Кулиева Ш.Х. Подготовка учителей профессионального образования на основе системного подхода // Scienceandworld. № 5 (45), 2017. - C. 70-72.

17. Кулиева Ш.Х. Содержание эффективности и качества подготовки будущих учителей трудового образования // Наука без границ. № 7(12)/ 2017. - С. 95-98. 